\begin{tabular}{ccl}
\hline Jurnal Teknologi Kimia Unimal & $\begin{array}{l}\text { Jurnal } \\
\text { Teknologi } \\
\text { Kimia } \\
\text { Unimal }\end{array}$ \\
\hline
\end{tabular}

\title{
OPTIMASI PROSES PEMBUATAN BIOPLASTIK DARI PATI LIMBAH KULIT SINGKONG
}

\author{
Suryati $^{1}$, Meriatna $^{2}$, Marlina $^{3}$ \\ ${ }^{123}$ Jurusan Teknik Kimia, Fakultas Teknik Universitas Malikussaleh, \\ Lhokseumawe
}

\begin{abstract}
ABSTRAK
Penelitian ini bertujuan mendapatkan kondisi proses optimum pengolahan plastik biodegradabel dari pati kulit singkong dengan bahan tambahan kitosan dan plasticizer gliserol. Hasil yang diperoleh berupa lembaran plastik tipis (film plastik) yang telah diuji biodegradabelitas, ketahanan air dan FT-IR. Hasil kondisi optimum yang diperoleh menunjukkan suhu optimum pengeringan berada pada $61,03 \circ \mathrm{C}$ dan waktu pengeringan 117 menit dengan perolehan biodegradabilitas $72,05 \%$, penyerapan air 25,68 \%. Hasil uji FT-IR menunjukkan bahwa plastik biodegradabel yang dihasilkan memiliki gugus fungsi $\mathrm{CH}, \mathrm{OH}$ dan $\mathrm{NH}$.
\end{abstract}

Kata kunci: Plastik Biodegradabel, Pati Kulit Singkong, Kitosan, Gliserol

\section{Pendahuluan}

Limbah plastik berbasis petroleum merupakan limbah yang tidak dapat diuraikan oleh mikroorganisme, sehingga menjadi masalah bagi lingkungan, oleh sebab itu dilakukan pengembangan plastik biodegradable dengan pemanfaatkan kulit singkong yang merupakan limbah yang tidak dimanfaatkan secara maksimal selama ini.

Plastik biodegradabel adalah plastik yang dapat terurai oleh aktivitas mikroorganisme menjadi hasil akhir berupa air dan gas karbondioksida, setelah habis terpakai dan dibuang ke lingkungan tanpa meninggalkan sisa yang beracun. Karena sifatnya yang dapat kembali ke alam, plastik biodegradabel merupakan bahan plastik yang ramah terhadap lingkungan (Pranamuda, 2009).

Kulit umbi singkong yang diperoleh dari produk tanaman singkong (Manihot Esculenta Cranz) merupakan limbah utama pangan di negara-negara berkembang. Semakin luas areal tanaman singkong diharapkan produksi umbi yang dihasilkan semakin tinggi yang pada gilirannya semakin tinggi pula limbah 
kulit yang dihasilkan. Setiap kilogram singkong biasanya dapat menghasilkan 15$20 \%$ kulit umbi. Kandungan pati kulit singkong yang cukup tinggi, memungkinkan digunakan sebagai pembuatan film plastik biodegradasi. Komponen kimia kulit singkong dapat dilihat pada Tabel 1.

Kulit singkong juga mengandung tannin, enzim peroksida, glukosa, kalsium oksalat, serat dan HCN. Kandungan pati yang berasal dari kulit singkong yang cukup tinggi memungkinkan digunakan sebagai film plastik biodegradasi. Potensi tersebut dapat digunakan sebagai peluang untuk memberikan nilai tambah pada kulit singkong sebagai bahan dasar dalam pembuatan kemasan plastik yang ramah lingkungan (Akbar dkk, 2013).

Tabel 1. Komponen kimia kulit singkong (per 100 gr kalori)

\begin{tabular}{|l|l|c|}
\hline No. & \multicolumn{1}{|c|}{ Komponen Kimia } & Kadar \\
\hline 1. & Protein & $1,20 \mathrm{gr}$ \\
\hline 2. & Phospohor & $40,00 \mathrm{mgr}$ \\
\hline 3. & Kalori & $146,00 \mathrm{kal}$ \\
\hline 4. & Vitamin C & $33,00 \mathrm{mg}$ \\
\hline 5. & Karbohidrat & $34,00 \mathrm{gr}$ \\
\hline 6. & Besi & $0,70 \mathrm{mgr}$ \\
\hline 7. & Air & $62,50 \mathrm{gr}$ \\
\hline 8. & Vitamin B1 & $0,06 \mathrm{mgr}$ \\
\hline
\end{tabular}

(Sumber : BPTTG Puslitbag Fisika Terapan-LIPI, 1990)

Sanjaya dan Puspita (2011) dalam penelitiannya mengkaji pengaruh penambahan kitosan dan plasticizer gliserol pada karakteristik plastik biodegradable dari pati limbah kulit singkong. Campuran pati dan kitosan serta gliserol sebagai plasticizer divariasikan $(3 \mathrm{ml} ; 5 \mathrm{ml} ; 7 \mathrm{ml}$ dan larutan kitosan $(0,5 \% ; 0,75 \% ; 1 \% ; 2 \%)$. Hasil penelitian terbaik pada komposisi kitosan $2 \%$, gliserol $3 \mathrm{ml}$ dengan nilai tensile strength sebesar 6269,059 psi, modulus young sebesar 494925,675 psi, dan elongasi sebesar 1,27\%. Dimana semakin banyak kitosan yang digunakan maka sifat mekanik dan ketahanan terhadap air semakin baik. Bioplastik terdegradasi dengan bantuan EM4 selama 10 hari.

Akbar dkk (2013) dalam penelitiannya mengkaji pengaruh waktu simpan film plastik biodegradasi dari pati kulit singkong terhadap sifat mekanikalnya. 
Hasil terbaik penelitian ini pati sebanyak 12 gram ditambah gliserol $4 \mathrm{ml}$, menghasilkan kekuatan tarik 0,2122 $\mathrm{kgf} / \mathrm{mm}$ dan pemanjangan saat putus sebesar $3,5 \%$. Uji biodegradasi film plastik didalam tanah bahwa plastik terdegradasi dalam waktu 14 hari.

Harnist dkk (2011) mengkaji kondisi optimum konsentrasi plasticizer pada sintesa plastik biodegradable berbahan dasar pati sorgum. Penelitian ini diambil kondisi terbaik formulasi pati kitosan 7:3 gram dan konsentrasi gliserol divariasikan pada 10\%, 15\%, 23\%, 27\%, 33\%, 35\%. Hasil penelitian diperoleh film bioplastik optimum pada formulasi pati-kitosan 7:3 gram adalah pada konsentrasi plastisizer gliserol 10\% dengan kekuatan tarik 0,525 Mpa, modulus young 542,437 Mpa dan ketahanan air 25\%.

\section{Metodologi}

Bahan yang digunakan dalam penelitian ini adalah: pati kulit singkong, kitosan (dari kulit udang DD 92\%), gliserol, $\mathrm{CH}_{3} \mathrm{COOH} 1 \%$ dan aquades. Metode yang digunakan terdiri dari tiga tahap. Tahap pertama proses ekstraksi pati singkong, tahap pengolahan pati singkong dengan penambahan gliserol dan kitosan dan tahap ketiga uji karakteristik bioplastik, meliputi: uji biodegradabilitas (\%), uji penyerapan terhadap air (\%) dan uji gugus fungsi (FTIR). Perbandingan pati:kitosan b/b (70:30), volume gliserol $3 \mathrm{~mL}$, suhu pemasakan $70^{\circ} \mathrm{C}$, dan waktu pengadukan 120 menit, kecepatan pengadukan $250 \mathrm{rpm}$, ukuran cetakan $(7 \mathrm{~cm} \mathrm{x}$ $7 \mathrm{~cm} \times 5 \mathrm{~mm}$ ), volume asam asetat $1 \%$ adalah $100 \mathrm{~mL}$. Variabel bebas yang digunakan: suhu pengeringan: $50^{\circ} \mathrm{C}, 60^{\circ} \mathrm{C}, 70^{\circ} \mathrm{C}$ dan waktu pengeringan adalah : 90 menit, 120 menit, dan 150 menit. Uji karakteristik bioplastik terdiri dari uji biodegradabilitas (\%), uji daya serap terhadap air dan uji gugus fungsi (FTIR). Desain eksperimen dan analisis hasil optimasi variabel proses yang berpengaruh dilakukan dengan menggunakan Central Composite Design dan Response Surface Methode (RSM) (Box et al ., 1978 ).

\section{Hasil dan Pembahasan}

Pengaruh Suhu dan Waktu Pengeringan terhadap Biodegradabilitas 
Biodegradabilitas menunjukkan persentase antara bobot plastik sesudah didegradasi terhadap bobot plastik sebelum didegradasi. Ketahanan dalam air menunjukkan persentase penggembungan plastik oleh adanya air. Desain rancangan penelitian dan hasil penelitian ditunjukkan pada Tabel 2.

Tabel 2 Desain rancangan penelitian dan hasil penelitian

\begin{tabular}{|l|l|l|l|l|}
\hline \multirow{2}{*}{ Run } & \multicolumn{2}{|l|}{ Variabel Bebas } & \multicolumn{2}{l|}{ Hasil Penelitian (Variabel Terikat) } \\
\cline { 2 - 5 } & Suhu $\left({ }^{\circ} \mathrm{C}\right)$ & $\begin{array}{l}\text { Waktu } \\
(\text { Menit})\end{array}$ & Biodegradabilitas $(\%)$ & Penyerapan Air $(\%)$ \\
\hline 1 & 60 & 90 & 67,74 & 30,39 \\
\hline 2 & 50 & 150 & 52,59 & 50,27 \\
\hline 3 & 70 & 90 & 58,33 & 45,14 \\
\hline 4 & 50 & 120 & 57,79 & 40,28 \\
\hline 5 & 70 & 150 & 49,43 & 29,51 \\
\hline 6 & 60 & 120 & 72,05 & 25 \\
\hline 7 & 60 & 150 & 62,70 & 34,5 \\
\hline 8 & 50 & 90 & 53,89 & 32,48 \\
\hline 9 & 70 & 120 & 62,16 & 27,64 \\
\hline
\end{tabular}

Persamaan regresi model orde II dalam penelitian ini merupakan Model Quadratik untuk masing-masing respon (variabel terikat) adalah sebagai berikut:

a. Untuk respon Biodegradabilitas:

Biodegradabilitas $=-498,81778+15,01217(X 1)+2,04289(X 2)-0,006333$

$$
(\mathrm{X} 1)(\mathrm{X} 2)-0,11798(\mathrm{X} 1)^{2}-0,007281(\mathrm{X} 2)^{2} \quad \ldots \quad \text { (1) }
$$

b. Untuk respon penyerapan air:

Ketahanan Air $=212,39333-6,11167(X 1)+0,085833(X 2)-0,02785(X 1)$

$$
(\mathrm{X} 2)+0,0759(\mathrm{X} 1)^{2}+0,00675(\mathrm{X} 2)^{2} \quad \ldots \quad \text { (2) }
$$

Keakuratan kedua model di atas dapat diketahui dari harga R-squared $\left(\mathrm{R}^{2}\right)$. Model Quadratik menunjukkan nilai R-squared masing-masing sebesar: model respon biodegradabilitas, $\mathrm{R}^{2}=0,9890$; dan model respon penyerapan air, $\mathrm{R}^{2}=0,9487$.

Dari kedua nilai tersebut dapat disimpulkan bahwa nilai biodegradabilitas dan penyerapan air yang diperkirakan dengan model mendekati nilai yang diperoleh dari hasil penelitian. Hal ini menandakan bahwa model orde 
dua sangat signifikan dan cukup layak untuk mewakili hubungan antara variabel respon dengan variabel independen. Untuk membuktikan kelayakan model orde dua ini perlu dilakukan analisa lebih lanjut melalui analisa varian dan uji kelayakan model.

Perbandingan nilai biodegradablitas antara eksperimen dengan prediksi dapat dilihat pada Tabel 3. Kolom 4 pada tabel tersebut merupakan nilai yang diperoleh dari eksperimen. Sementara itu nilai-nilai pada kolom 5 merupakan nilai variabel tanggap rendemen yang dihitung berdasarkan persamaan 1. Meninjau Tabel 3 terlihat bahwa persentase kesalahan pada setiap titik yang ditinjau cukup kecil, walaupun pada beberapa titik terjadi kesalahan yang relatif besar, terutama pada biodegradablitas yang kesalahannya mendekati 1,81\%. Namun kesalahan yang terjadi pada biodegradablitas rata-rata $\pm-0,052 \%$.

Tabel 3 Validasi hasil prediksi model terhadap data eksperimen (biodegradabilitas)

\begin{tabular}{|c|c|c|c|c|c|}
\hline \multirow{2}{*}{ Run } & \multicolumn{2}{|c|}{} & \multicolumn{3}{c|}{ Variabel Tanggap } \\
\cline { 3 - 6 } & \multicolumn{2}{|c|}{ Variabel } & \multicolumn{3}{c|}{ Biodegradabilitas } \\
\cline { 2 - 6 } & $\begin{array}{c}\text { Suhu } \\
\left({ }^{\circ} \mathrm{C}\right)\end{array}$ & $\begin{array}{c}\text { Waktu } \\
(\text { Menit })\end{array}$ & Eksperimen & Prediksi & \% Penyimpangan \\
\hline 1 & 60 & 90 & 67,74 & 67,87 & $-0,19$ \\
\hline 2 & 50 & 150 & 52,59 & 51,95 & 1,21 \\
\hline 3 & 70 & 90 & 58,33 & 58,92 & $-1,01$ \\
\hline 4 & 50 & 120 & 57,79 & 59,14 & $-2,34$ \\
\hline 5 & 70 & 150 & 49,43 & 50,05 & $-1,25$ \\
\hline 6 & 60 & 120 & 72,05 & 71,89 & 0,23 \\
\hline 7 & 60 & 150 & 62,70 & 62,80 & $-0,16$ \\
\hline 8 & 50 & 90 & 53,89 & 53,23 & 1,23 \\
\hline 9 & 70 & 120 & 62,16 & 61,04 & 1,81 \\
\hline
\end{tabular}

Tabel 4 menunjukkan perbandingan nilai penyerapan air antara eksperimen dengan prediksi. Dapat dijelaskan bahwa kolom 4 pada tabel tersebut merupakan nilai yang diperoleh dari eksperimen. Sementara itu nilai-nilai pada kolom 5 merupakan nilai variabel tanggap ketahanan plastik dalam air yang dihitung berdasarkan persamaan 2 . 
Tabel 4 Validasi hasil prediksi model terhadap data eksperimen (Penyerapan air)

\begin{tabular}{|c|c|c|c|c|c|}
\hline \multirow{2}{*}{ Run } & \multicolumn{2}{|c|}{} & \multicolumn{3}{c|}{ Variabel Tanggap } \\
\cline { 4 - 6 } & \multicolumn{2}{|c|}{ Variabel } & \multicolumn{3}{c|}{ Penyerapan air } \\
\hline & $\begin{array}{c}\text { Suhu } \\
\left({ }^{\circ} \mathrm{C}\right)\end{array}$ & $\begin{array}{c}\text { Waktu } \\
(\text { Menit})\end{array}$ & Eksperimen & Prediksi & \% Penyimpangan \\
\hline 1 & 60 & 90 & 30,39 & 30,94 & $-1,82$ \\
\hline 2 & 50 & 150 & 50,27 & 52,43 & $-4,31$ \\
\hline 3 & 70 & 90 & 45,14 & 43,43 & 3,79 \\
\hline 4 & 50 & 120 & 40,28 & 36,96 & 8,24 \\
\hline 5 & 70 & 150 & 29,51 & 28,81 & 2,37 \\
\hline 6 & 60 & 120 & 25 & 25,91 & $-3,65$ \\
\hline 7 & 60 & 150 & 34,5 & 33,03 & 4,25 \\
\hline 8 & 50 & 90 & 32,48 & 33,63 & $-3,56$ \\
\hline 9 & 70 & 120 & 27,64 & 30,05 & $-8,71$ \\
\hline
\end{tabular}

Meninjau Tabel 3 terlihat bahwa persentase kesalahan pada setiap titik yang ditinjau cukup kecil, walaupun pada beberapa titik terjadi kesalahan yang relatif besar, terutama pada penyerapan air yang kesalahannya mendekati 8,24\%. Namun kesalahan yang terjadi pada ketahanan dalam air rata-rata $\pm-0,37 \%$.

Dari hasil kesalahan pada Tabel 3 dan 4 yang relatif cukup kecil dapat disimpulkan bahwa model yang diusulkan cukup absah untuk menyatakan hubungan antara variabel tanggap dengan variabel independen. Validasi hasil hasil prediksi terhadap data hasil eksperimen merupakan salah satu cara untuk membuktikan keabsahan model yang diusulkan.

Plastik yang terbuat dari pati kulit singkong diuji sifat biodegradabilitasnya dengan menguburkan plastik di dalam tanah dengan kedalaman $20 \mathrm{~cm}$ dan luas (20x20) $\mathrm{cm}$ dan ditimbang beratnya sebelum dikuburkan dan setelah dikuburkan setiap minggunya sampai terurai. Proses uji degradabilitas ini diperlukan untuk mempelajari tingkat ketahanan plastik yang dihasilkan yang berkaitan dengan pengaruh mikroba pengurai, kelembaban tanah dan suhu bahkan faktor kimia fisik yang lain. Secara kimiawi, plastik yang dihasilkan jelas bersifat biodegradabilitas, hal itu disebabkan oleh bahan baku yang digunakan 
adalah bahan baku organik dan alamiah yang mudah berinteraksi dengan air dan mikroorganisme lain bahkan sensitif terhadap pengaruh fisik atau kimia lingkungan.

Biodegradabilitas yang dihasilkan berkisar antara 49,43\% - 72,05\%, bervariasi menurut kondisi operasi. Biodegradabilitas yang diperoleh dipengaruhi oleh perubahan suhu dan waktu pengeringan. Pengaruh suhu dan pengeringan terhadap biodegradabilitas ditunjukkan pada Gambar 1 dan 2.

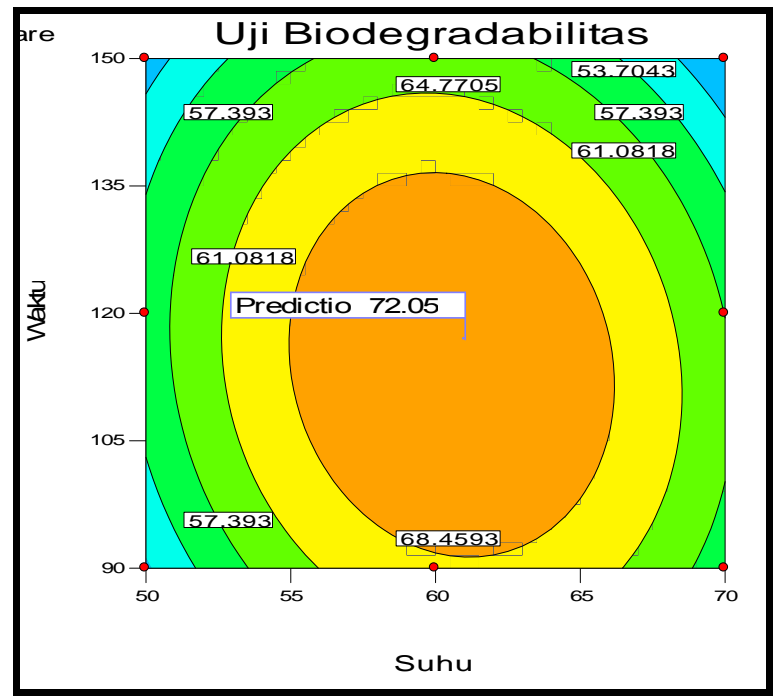

Gambar 1 Contour plot biodegradabilitas sebagai fungsi suhu dan waktu pengeringan 
biodegradable yang menyebabkan plastik biodegradable tersebut memilki ketahanan terhadap air, hal ini karena kitosan sendiri adalah senyawa yang bersifat hidrofobik. Pengaruh suhu dan waktu pengeringan terhadap kadar air ditunjukkan pada Gambar 3 dan 4.

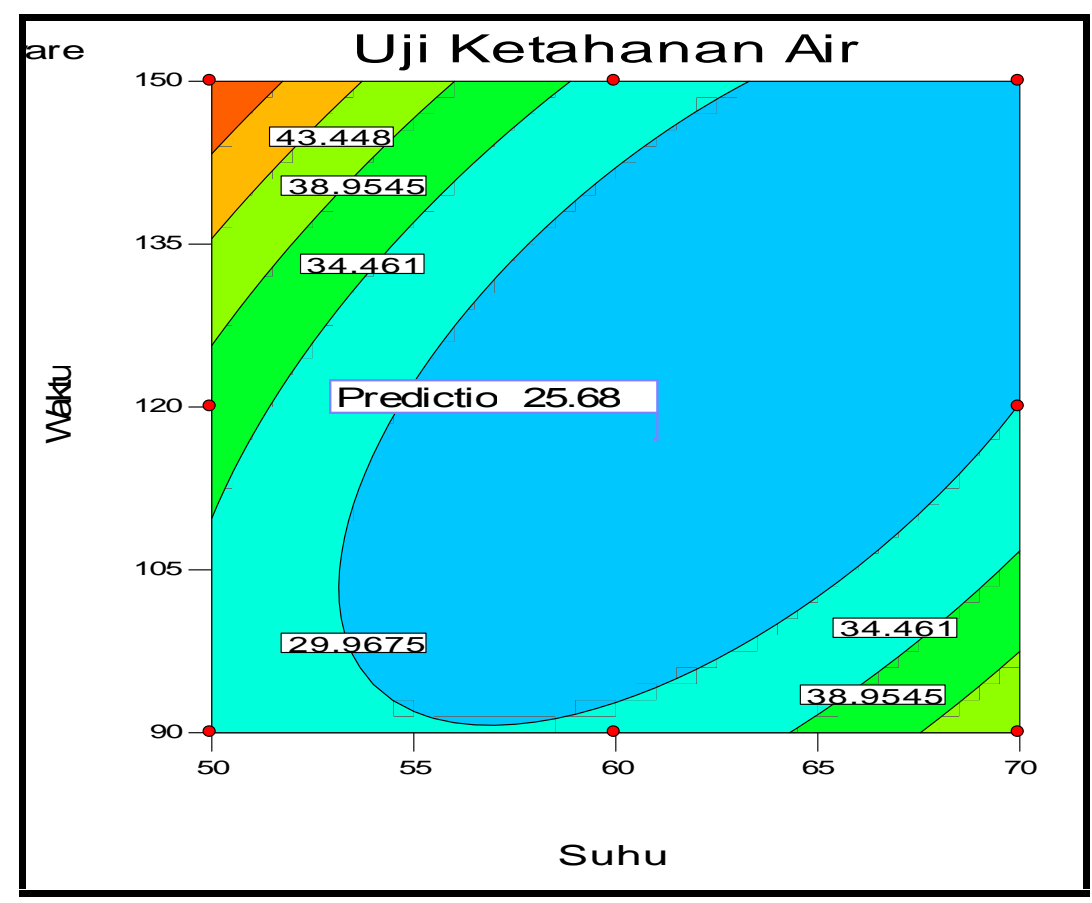

Gambar 3 Contour plot ketahanan dalam air sebagai fungsi suhu dan waktu pengeringan 


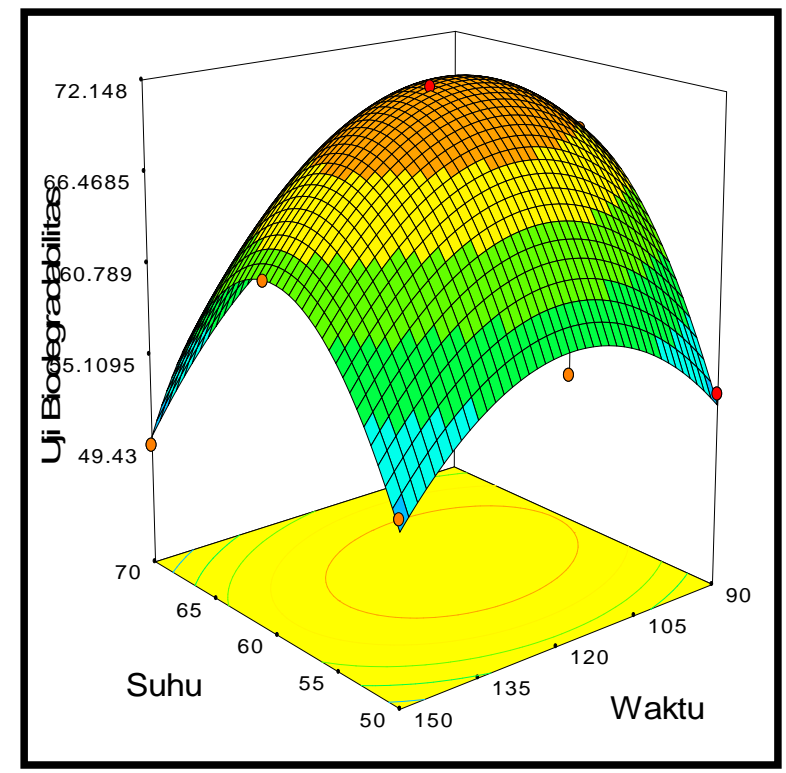

Gambar 4 Surface plot ketahanan dalam air sebagai fungsi suhu dan waktu pengeringan

Pada Gambar 3 terlihat grafik kontur dan Gambar 4 surface plot tiga dimensi yang menggambarkan persentase ketahanan dalam air dengan variasi suhu dan waktu. Kedua gambar tersebut menunjukkan bahwa grafik surface plot dan contour plot mempunyai bentuk minimum. Dari gambar tersebut dapat diketahui bahwa persentase ketahanan dalam air terbaik diperoleh pada suhu $61^{\circ} \mathrm{C}$ dan waktu 117 menit yaitu 25,68 \%. Hal ini menunjukkan bahwa interaksi antara suhu dan waktu berpengaruh nyata terhadap penyerapan air.

Semakin tinggi suhu dan waktu pengeringan yang digunakan maka mempengaruhi penguapan kitosan dalam bioplastik, sehingga bioplastik yang dihasilkan mengandung sedikit kitosan dan mempengaruhi sifat bioplastik yaitu menjadi hidrofilik sehingga plastik semakin banyak menyerap air.

Optimasi bertujuan untuk mendapatkan bioplastik dengan memberikan biodegradabilitas yang tinggi dan penyerapan air yang rendah. Hal ini dilakukan karena berhubungan dengan biaya operasional yang minimum. Untuk menekan biaya operasi, maka suhu harus seminimum mungkin, karena semakin besar suhu pengeringan semakin banyak biaya yang diperlukan. Begitu juga dengan, semakin 
lama waktu pengeringan semakin banyak daya yang dikeluarkan. Konsekuensinya akan semakin besar biaya yang dikeluarkan. Sementara itu biodegradabilitas yang diharapkan semaksimal mungkin dan penyerapan air yang seminimal mungkin. Sehingga optimasi suhu dan waktu yang diharapkan untuk memperoleh biodegradabilitas yang tinggi $\left(\mathrm{Y}_{1}\right)$ dan ketahanan dalam air yang rendah $\left(\mathrm{Y}_{2}\right)$.

\section{Analisis Gugus Fungsi (FT-IR) Pada Plastik Biodegradable}

Uji FT-IR (Fourier Transform Infrared Spectroscopy) sebagai analisis yang dilakukan untuk menentukan gugus fungsi pada plastik biodegradable. Contoh spektrum FT-IR yang dihasilkan disajikan dalam Gambar 5. Identifikasi gugus fungsi dalam sampel berdasarkan posisi pita serapan dalam spektrum yang disajikan dalam Gambar 5 dan mengacu pada tabel FT-IR disajikandalam Tabel 5.

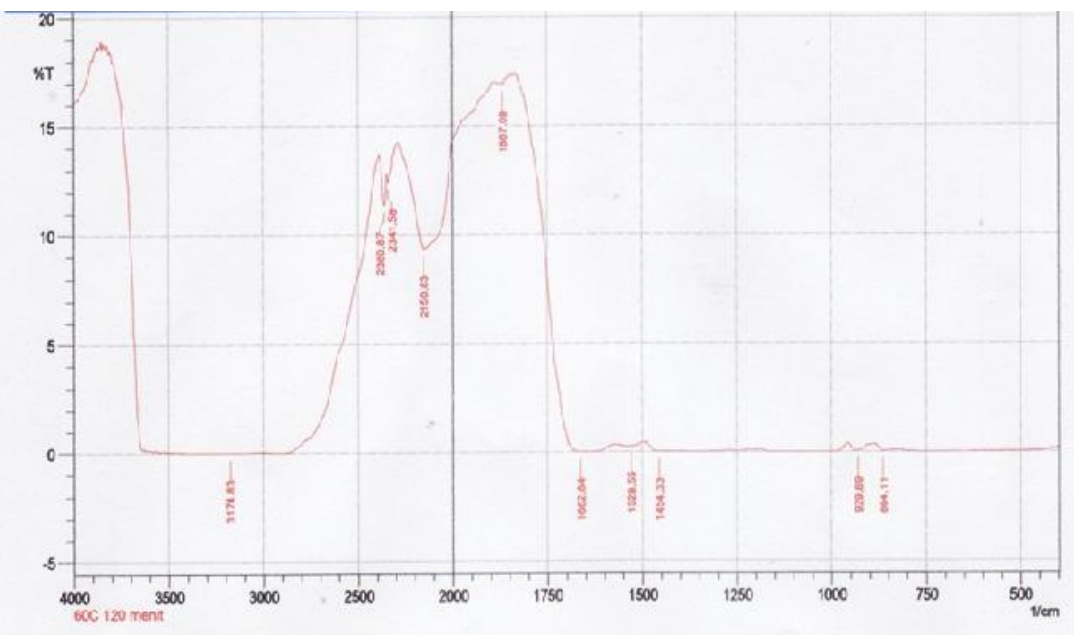

Gambar 5 Spektrum FT-IR Plastik Biodegradable

Tabel 5 Hasil Analisis Gugus Fungsi dengan FT-IR

\begin{tabular}{|l|l|l|}
\hline $\begin{array}{l}\text { Bilangan Gelombang }\left(\mathrm{cm}^{-1}\right) \\
(\text { Uji FTIR) }\end{array}$ & Gugus Fungsi & Rentang Bilangan Gelombang \\
\hline \multicolumn{1}{|c|}{2360,87} & C-H alkana & $2250-2960$ \\
\hline 2150,63 & O-H alkohol & $2000-3600$ \\
\hline 3750,00 & N-H amin & $3310-3800$ \\
\hline
\end{tabular}

Berdasarkan Gambar 5 dapat terlihat bahwa gugus fungsi pada plastik biodegradable merupakan gabungan dari gugus fungsi spesifik yang terdapat pada 
masing-masingkomponen penyusun plastik biodegradable tersebut. Gugus gabungan tersebut terbentuk akibat adanya proses modifikasi pati yang disebut dengan grafting atau pencangkokan dimana terjadi perubahan letak gugus fungsi, gugus $\mathrm{OH}^{-}$putus dan berganti posisi dengan gugus dari kitosan dan gliserol. Berdasarkan hal tersebut terlihat dengan jelas bahwa plastik biodegradable yang dihasilkan memiliki gugus yang relatif sama dengan komponen penyusunnya sehingga dapat disimpulkan pula bahwa plastik yang terbentuk masih tetap memiliki sifat hidrofilik seperti komponen penyusunnya akan tetapi dengan proses grafting sifat hidrofilik tersebut mampu dikurangi, dimana persen air terserap pada pati yaitu sekitar $100 \%$ telah dapat dikurangi menjadi $25, \%$ dengan memodifikasi pati dengan metoda grafting. Sifat hidrofilik dari plastik biodegradable ini juga dapat dilihat dari adanya gugus $\mathrm{OH}^{-}$pada plastik biodegradable yang terdapat pada bilangan gelombang $2150,63 \mathrm{~cm}^{-1}$. Selain gugus hidroksida $(\mathrm{OH})$, pada $2360,87 \mathrm{~cm}^{-1}$, adanya gugus $(\mathrm{CH})$ alkana yang berasal dari pati dan kitosan dan gugus adanya gugus $(\mathrm{NH})$ amin yang diduga berasal dari kitosan yang terlihat pada bilangan gelombang $3750,00 \mathrm{~cm}^{-1}$ dan untuk lebih jelas dapat dilihat pada Tabel 5. Struktur ikatan kimia antara pati, kitosan dan gliserol dapat juga ditandai dengan adanya beberapa gugus fungsi antara lain, CH-pati, OH-gliserol dan NH - kitosan (Harnis dan Darni, 2011).

\section{Kesimpulan}

Berdasarkan hasil penelitian dan pengolahan data, maka dapat diambil kesimpulan:

1. Kondisi operasi optimum proses pembuatan plastik biodegradable pada kombinasi variabel bebas yaitu suhu pengeringan $61,03^{\circ} \mathrm{C}$ dan waktu pengeringan 117 menit.

2. Dari perhitungan berdasarkan model yang diperoleh, hasil respon (variabel terikat) yang optimal adalah biodegradabilitas 72,05\%, penyerapan air 25,68\% dan berdasarkan eksperiment adalah biodegradabilitas $72,1 \%$, dan penyerapan air $25,50 \%$. 
3. Hasil uji FTIR menunjukkan bahwa plastik biodgradable yang dihasilkan memiliki gugus fungsi $\mathrm{CH}, \mathrm{OH}$ dan $\mathrm{NH}$ yang diduga berasal dari pati, gliserol dan kitosan

4. Bioplastik yang dihasilkan termasuk dalam golongan biodgradable, karena biodegradabilitas lebih dari $70 \%$.

\section{Daftar Pustaka}

Ahvenainen, Raija, 2003. Modern Plastics Handbook (edisi ke-1st).

Akbar, Fauzi dkk.., 2013 Jurnal Pengaruh Waktu Simpan Film Plastik Biodegradable Dari Pati Kulit Singkong Terhadap Sifat Mekanikalnya,Teknik Kimia USU, Diakses 3 Oktober 2013.

Bradley, N. 2007. Response Surface Methodology. Indiana university of south . Bend. Fardiaz.1989. Dasar Tekhnologi Pangan.

Box, G. E. P. and Draper, N. R. ,1987., Empirical Model Building and Response Surfaces, New York: John Wiley \& Sons.

Christianty, Maria Ulfa., 2009. Produksi Biodegradable Plastic Melalui Pencampuran pati Sagu Termoplastis dan Compatibilized Linear Low Density polyethylene.Sekolah Pascasarjana Institut Pertanian Bogor.

Eva, Arifah dkk., 2010. Laporan Praktikum Teknologi Pati dan Gula "Gula Merah, Gula Invert dan Gula Semut dan Analisis Produk Gula”, Departemen Teknologi Industri Pertanian, Fakultas Teknologi Pertanian Institut Pertanian, Bogor.

Firdaus, Feris dan Chairir A., 2004, Potensi Limbah Pada-Cair Industri Tepung Tapioka Sebagai Bahan Baku Pembuatan Film Plastik Biodegradable, Peneliti Dilembaga Penelitian Uii Jokjakarta Dan Dosen Pasca Sarjana UGM Jokjakarta.

Harnist, Ricki dan Darni, Yuli. 2011. Penentuan Kondisi Optimum Kondisi Plasticizer pada Sintesa Plastik Biodegradable berbahan Dasar pati Sorgum, chemical Engineering, Engineering Faculty, lampung University.

Humaira, Plastik Ramah Lingkungan Dari Lidah Buaya, diakses 21 April 2013.

Koswara S, 2006, Plastik Ramah Lingkungan diakses 2 April 2013.

Puspita, Tyas dan M.H. Sanjaya, Gede, 2011. Pengaruh Penambahan Khitosan dan Plasticizer Gliserol Pada Karakteristik Plastik Biodegradable Dari Pati Limbah Kulit Singkong, Jurusan Teknik Kimia FT-ITS. 
Rahman, dkk, 2010, Jurnal Program Kreativitas Mahasiswa Inovasi Baru Pengembangan Hidrolisa Pati Bonggol pisang Sebagai Sumber Utama Pembuatan Plastik Biodegradable Poly-B -Hidroksialkanoat, Institut Pertanian Bogor, diakses 20 Mei 2013.

Sudjana. 2002. Metode Statistika. Bandung: Tarsito. 